\title{
With expanded carrier screening, founder populations run the risk of being overlooked
}

\author{
Inge B. Mathijssen ${ }^{1}$ - Merel C. van Maarle ${ }^{1}$ • Iris I.M. Kleiss ${ }^{1}$ - Egbert J.W. Redeker ${ }^{1}$ • \\ Leo P. ten Kate ${ }^{2,3}$ - Lidewij Henneman ${ }^{2,3}$ - Hanne Meijers-Heijboer ${ }^{1,2}$
}

Received: 24 February 2017 / Accepted: 16 May 2017 / Published online: 29 May 2017

(C) The Author(s) 2017. This article is an open access publication

\begin{abstract}
Genetically isolated populations exist worldwide. Specific genetic disorders, including rare autosomal recessive disorders may have high prevalences in these populations. We searched for Dutch genetically isolated populations and their autosomal recessive founder mutations. We investigated whether these founder mutations are covered in the (preconception) expanded carrier screening tests of five carrier screening providers. Our results show that the great majority of founder mutations are not covered in these screening panels, and these panels may thus not be appropriate for use in founder populations. It is therefore important to be aware of founder mutations in a population when offering carrier tests.
\end{abstract}

Keywords Founder population · Community $\cdot$ Carrier screening $\cdot$ Autosomal recessive $\cdot$ Netherlands

\section{Introduction}

The general Dutch population is relatively outbred (Ten Kate et al. 2014). However, several genetically isolated populations

This article is part of the Topical Collection on Inclusion of Diverse Populations in Genomics Research and Health Services: A Scientific and Health Equity Imperative

Inge B. Mathijssen

i.b.mathijssen@amc.uva.nl

1 Department of Clinical Genetics, Academic Medical Center, Amsterdam, The Netherlands

2 Department of Clinical Genetics, VU University Medical Center, Amsterdam, The Netherlands

3 Amsterdam Public Health Research Institute, VU University Medical Center, Amsterdam, The Netherlands exist (for definitions of terms see Box 1). Also, in many other countries worldwide, genetically isolated populations are present. Often these populations are geographically, culturally, or for religious reasons isolated for centuries and as a consequence show less genetic variation. Because of the low genetic heterogeneity, these populations have proven to be very suitable for the identifications of genes involved both in Mendelian as well as in complex disorders. Bottleneck effects in the history of a population and/or founder effects may result in high prevalences of monogenic recessive disorders in these populations compared with the nationwide prevalences.

Because of high carrier frequencies in founder populations, carrier screening programs have been introduced in some of these populations. The aim of these programs is to identify carrier couples with a one-in-four risk of affected offspring, enabling autonomous reproductive decision making, which consequently might reduce perinatal morbidity and mortality. Examples are carrier screening programs for genetic disorders in people of Eastern European Jewish (Ashkenazi) descent (for example Tay-Sachs disease) (ACOG Committee on

\section{Box 1 Definitions}

Genetically isolated population or founder population: a population that is or was geographically, culturally, or for religious reasons isolated and as a consequence has restricted genetic variation.

Bottleneck effect: occurs when there is a sharp reduction in the size of a population due to a natural disaster or similar event with, as a consequence, reduction of the genetic variation in the population.

Founder effect: the reduction of genetic variation that occurs when a new population is founded by a small number of individuals (founders) from a larger population and this population remains isolated to other populations.

Founder mutation: a gene mutation on an identical haplotype background, observed with high frequency in a genetically isolated population in which one or more of the ancestors were carriers of the gene mutation.

Recurrent mutation: a gene mutation on more than one haplotype background, reoccurring multiple times in a population history. 
Genetics 2009), targeted carrier screening for severe and frequent disorders in different isolated (mainly Arab and Druze) communities in Israel (Basel-Vanagaite et al. 2007; FalikZaccai et al. 2008; Zlotogora et al. 2009), screening for four recessive diseases in the Saguenay-Lac-Saint-Jean region of Quebec, Canada (Tardif et al. 2017), and screening for four severe autosomal recessive disorders in a Dutch genetically isolated community (Mathijssen et al. 2015).

Meanwhile, technological advances have enabled the development and offer of preconception expanded carrier screening (ECS) in which couples without an a priori increased risk of having a child with a genetic disorder can be screened for several (hundreds of) disorders simultaneously (Edwards et al. 2015; Henneman et al. 2016). An increasing number of mainly commercial laboratories offer these screening panels (Borry et al. 2011; Lazarin et al. 2013).

However, the carrier frequencies of several autosomal recessive disorders in genetically isolated populations can be very skewed from nationwide or worldwide carrier frequencies. In some genetically isolated populations, carrier frequencies of disorders which are rare or almost non-existent in the general population may be very high. In contrast, carrier frequencies of more frequent disorders in the general population may be very low in genetically isolated populations.

The aim of this study was to make an inventory of Dutch genetically isolated populations and their autosomal recessive founder mutations, and to investigate whether Dutch founder mutations are covered in the (preconception) expanded carrier screening tests of carrier screening providers.

\section{Methods}

We searched for genetically isolated populations in the Netherlands (total population 17 million people) and their founder mutations in the databases PubMed, On-line Mendelian Inheritance in Man (OMIM), and Google semisystematically by using the keywords "genetically isolated population," "founder," "mutation," "gene," and "Dutch" or "Netherlands." Also, 11 Dutch clinical (molecular) geneticists were asked about their knowledge of genetically isolated populations and their specific founder mutations. Only autosomal recessive mutations were included. Recurrent mutations (Box 1) and Dutch founder mutations not related to a specific genetically isolated community were not included (Zeegers et al. 2004). To prevent possible stigmatization, the genetically isolated populations are numbered and the specific names of the villages are not mentioned.

Our purpose was not to be complete, but to illustrate the importance of being aware of founder populations and founder mutations. We therefore made a selection of founder mutations present in different genetically isolated populations for which the most information was available in the literature and from personal information.

Information about the carrier frequencies of founder mutations were derived from the scientific articles and personal communication with clinical (molecular) geneticists. Carrier frequencies in the Dutch general population were derived from The Genome of the Netherlands (GoNL) project (http://www.nlgenome.nl, accessed 24 February 2017) (The Genome of the Netherlands Consortium 2014).

We investigated whether the specific founder mutations were present or absent in the expanded carrier screening panels offered by five ECS providers.

\section{Results}

In Table 1, several founder mutations present in six different Dutch genetically isolated populations are shown, including the carrier frequencies of these disorders in the specific genetically isolated population and in the Dutch general population. As can be seen, the carrier frequencies of generally rare disorders are high in these genetically isolated populations.

For the five selected carrier screening providers, the coverage of 16 founder mutations in the carrier screening tests is shown. For each carrier screening provider, on average 2.8 (range $0-5$ ) of the 16 founder mutations are covered in the test. Eleven (69\%) of the founder mutations are covered in none of the five carrier screening tests. In the test of two providers, a selection of mutations in the specific gene of three disorders is included in the carrier screening test, but the founder mutation is not.

\section{Discussion}

In genetically isolated populations, carrier frequencies of genetic disorders can be very different from the carrier frequencies in the general population. The great majority of these founder mutations are not covered in the ECS panels of the five selected providers. This also applies to most of the founder mutations present in genetically isolated populations in other countries.

Offering a (commercial) routine ECS panel to inhabitants of these genetically isolated populations is not appropriate because it may give false reassurance to couples with an increased risk for founder mutations related disorders they are not being tested for.

For a reliable carrier test offer, it is therefore important to know the genetically isolated populations and their founder mutations in each country. Nationwide databases in which the genetically isolated populations, their relatively frequent genetic disorders, and the specific genes and mutations are listed, are a suitable solution. A database is not only very important 


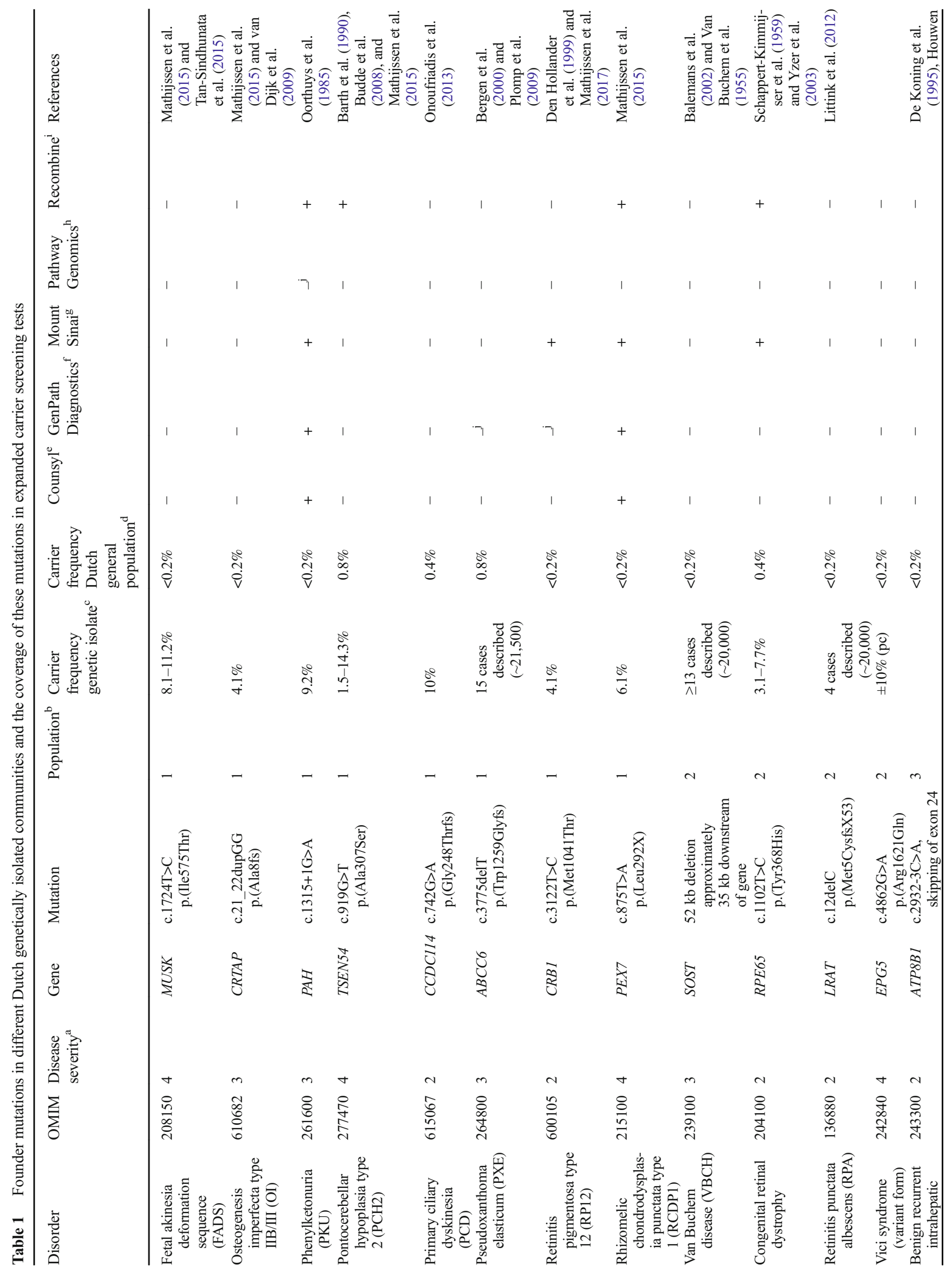




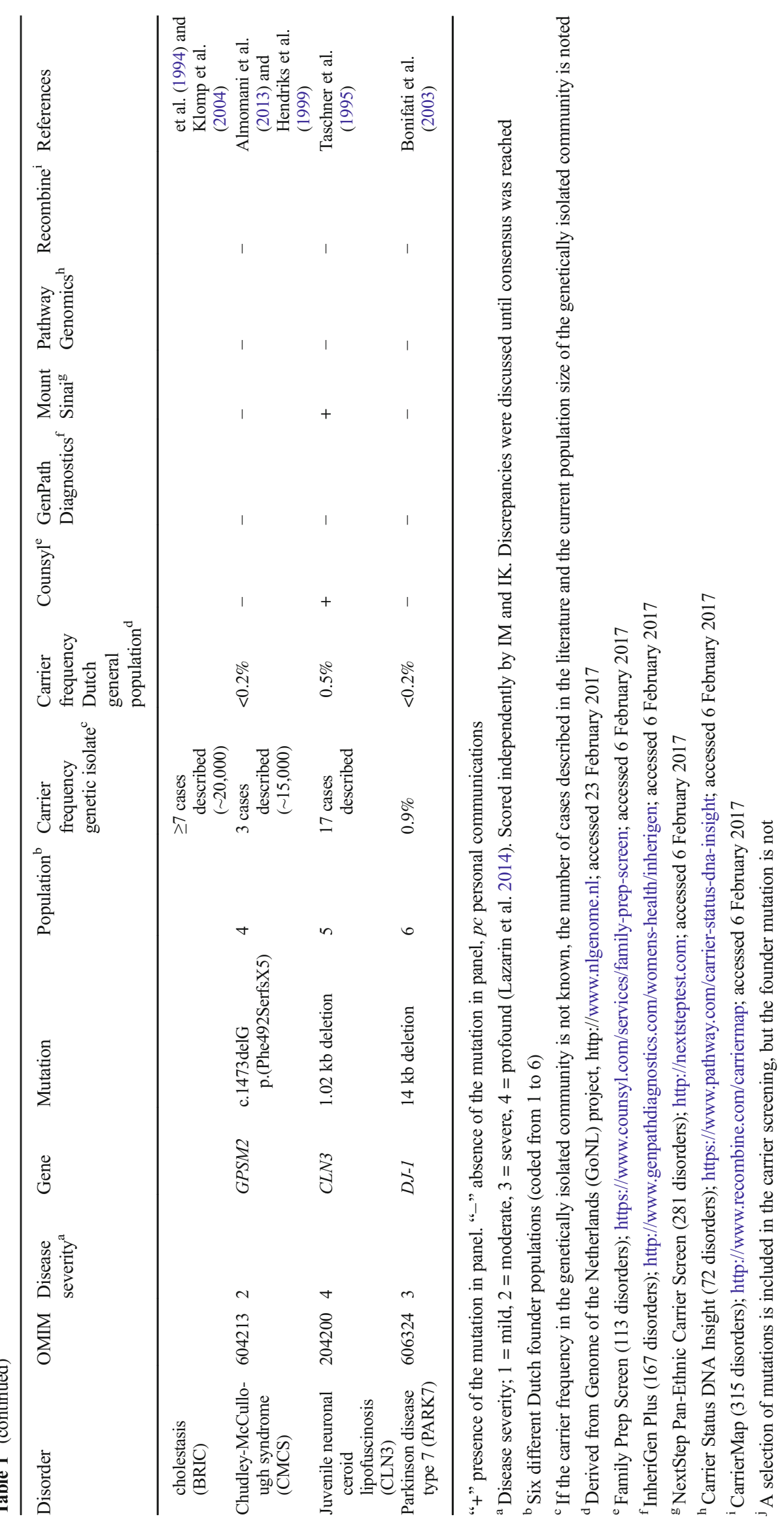


for carrier screening programs but also for making a rapid (differential) diagnosis by clinicians, genetic counseling, and research in these populations. For some genetically isolated populations such (online) databases are already available. Examples are the Amish, Mennonite, and Hutterite Genetic Disorder Database (www.biochemgenetics.ca/plainpeople) (Payne et al. 2011) and the Israeli National Genetic Database (www.goldenhelix.org/israeli) (Zlotogora 2010).

Ideally, a customized carrier test will be developed for each country/region in which both country/region-specific mutations as well as genetic isolate-specific founder mutations are present. This approach may also reduce potential stigmatization of genetic isolates, while specific mutations still are included.

In the Netherlands, carrier screening is only (partly) paid by health insurance companies in case of an increased risk of being a carrier; e.g. carrier screening for four autosomal recessive disorders in a genetically isolated community (Mathijssen et al. 2015) and carrier screening for nine disorders in individuals of Ashkenazi Jewish descent (Holtkamp et al. 2016). Recently, the Academic Medical Center in Amsterdam started a non-profit offer of carrier screening for 50 severe autosomal recessive disorders. Most of the severe disorders currently known in Dutch genetically isolated populations are included. Probably, in a non-commercial setting, it will be more likely to take into account the founder mutations present in founder populations than for commercial companies to include those mutations.

It is expected that in the near future, it will become possible to use whole-exome sequencing (WES) or whole-genome sequencing (WGS) for ECS, in which all known disease genes can be screened, including very rare disease genes prevalent in genetically isolated populations. However, correct interpretation of test-results (e.g. variants of unknown clinical significance) when using WES or WGS is complex. Also, the identification of carrier couples for mild disorders which are unlikely to alter reproductive plans is an important point to take into consideration (Beaudet 2015; Sallevelt et al. 2016).

In the meantime, descendants from genetically isolated populations should be made aware that a (commercial) routine ECS panel may not be appropriate and can give false reassurance because the population-specific genes and/or mutations are not covered. Currently, this information is not mentioned by expanded carrier test providers.

Not only genetically isolated populations but also consanguineous couples and populations with a high rate of consanguineous unions have an increased risk of having a child with an autosomal recessive disorder (Teeuw et al. 2014). Many of these disorders are rare disorders which are also not covered in the (commercial) routine ECS panels. These panels may therefore also not be appropriate for use in consanguineous couples and in countries/populations with a high rate of consanguineous unions.

\section{Conclusions}

In genetically isolated populations, carrier frequencies of generally rare autosomal recessive founder mutations can be very high. The great majority of these founder mutations are not covered in most (commercial) routine ECS panels. It is important to be aware of founder populations and founder mutations when using these ECS panels and to check whether the mutations are covered. If these founder mutations are not covered, customized screening tests should be developed which include the founder mutations.

\section{Compliance with ethical standards}

Conflict of interest All authors are affiliated to a hospital that offers expanded carrier screening in a non-commercial setting.

Funding LH supervises research evaluating carrier screening, financially supported by the Netherlands Organization for Health Research and Development (ZonMw grant no. 209040001).

Consent This article does not contain any studies with human participants performed by any of the authors.

Open Access This article is distributed under the terms of the Creative Commons Attribution 4.0 International License (http:// creativecommons.org/licenses/by/4.0/), which permits unrestricted use, distribution, and reproduction in any medium, provided you give appropriate credit to the original author(s) and the source, provide a link to the Creative Commons license, and indicate if changes were made.

\section{References}

ACOG Committee on Genetics (2009) ACOG Committee opinion no. 442: preconception and prenatal carrier screening for genetic diseases in individuals of Eastern European Jewish descent. Obstet Gynecol 114:950-953

Almomani R, Sun Y, Aten E, Hilhorst-Hofstee Y, Peeters-Scholte CM, van Haeringen A, Hendriks YM, den Dunnen JT, Breuning MH, Kriek M, Santen GW (2013) GPSM2 and Chudley-McCullough syndrome: a Dutch founder variant brought to North America. Am J Med Genet A 161A:973-976

Balemans W, Patel N, Ebeling M, van Hul E, Wuyts W, Lacza C, Dioszegi M, Dikkers FG, Hildering P, Willems PJ, Verheij JB, Lindpaintner K, Vickery B, Foernzler D, van Hul W (2002) Identification of a $52 \mathrm{~kb}$ deletion downstream of the SOST gene in patients with van Buchem disease. J Med Genet 39:91-97

Barth PG, Vrensen GF, Uylings HB, Oorthuys JW, Stam FC (1990) Inherited syndrome of microcephaly, dyskinesia and pontocerebellar hypoplasia: a systemic atrophy with early onset. J Neurol Sci 97:2542

Basel-Vanagaite L, Taub E, Halpern GJ, Drasinover V, Magal N, Davidov B, Zlotogora J, Shohat M (2007) Genetic screening for autosomal recessive nonsyndromic mental retardation in an isolated population in Israel. Eur J Hum Genet 15:250-253

Beaudet AL (2015) Global genetic carrier testing: a vision for the future. Genome Med 7:79

Bergen AA, Plomp AS, Schuurman EJ, Terry S, Breuning M, Dauwerse H, Swart J, Kool M, van Soest S, Baas F, ten Brink JB, de Jong PT 
(2000) Mutations in ABCC6 cause pseudoxanthoma elasticum. Nat Genet 25:228-231

Bonifati V, Rizzu P, van Baren MJ, Schaap O, Breedveld GJ, Krieger E, Dekker MC, Squitieri F, Ibanez P, Joosse M, van Dongen JW, Vanacore N, van Swieten JC, Brice A, Meco G, van Duijn CM, Oostra BA, Heutink P (2003) Mutations in the DJ-1 gene associated with autosomal recessive early-onset parkinsonism. Science 299: 256-259

Borry P, Henneman L, Lakeman P, ten Kate LP, Cornel MC, Howard HC (2011) Preconceptional genetic carrier testing and the commercial offer directly-to-consumers. Hum Reprod 26:972-977

Budde BS, Namavar Y, Barth PG, Poll-The BT, Nurnberg G, Becker C, van Ruissen F, Weterman MA, Fluiter K, te Beek ET, Aronica E, van der Knaap MS, Hohne W, Toliat MR, Crow YJ, Steinling M, Voit T, Roelenso F, Brussel W, Brockmann K, Kyllerman M, Boltshauser E, Hammersen G, Willemsen M, Basel-Vanagaite L, Krageloh-Mann I, de Vries LS, Sztriha L, Muntoni F, Ferrie CD, Battini R, Hennekam RC, Grillo E, Beemer FA, Stoets LM, Wollnik B, Nurnberg P, Baas F (2008) tRNA splicing endonuclease mutations cause pontocerebellar hypoplasia. Nat Genet 40:1113-1118

De Koning TJ, Sandkuijl LA, de Schryver JE, Hennekam EA, Beemer FA, Houwen RH (1995) Autosomal-recessive inheritance of benign recurrent intrahepatic cholestasis. Am J Med Genet 57:479-482

Den Hollander AI, ten Brink JB, de Kok YJ, van Soest S, van den Born LI, van Driel MA, van de Pol DJ, Payne AM, Bhattacharya SS, Kellner U, Hoyng CB, Westerveld A, Brunner HG, BleekerWagemakers EM, Deutman AF, Heckenlively JR, Cremers FP, Bergen AA (1999) Mutations in a human homologue of Drosophila crumbs cause retinitis pigmentosa (RP12). Nat Genet 23:217-221

Edwards JG, Feldman G, Goldberg J, Gregg AR, Norton ME, Rose NC, Schneider A, Stoll K, Wapner R, Watson MS (2015) Expanded carrier screening in reproductive medicine-points to consider: a joint statement of the American College of Medical Genetics and Genomics, American College of Obstetricians and Gynecologists, National Society of Genetic Counselors, Perinatal Quality Foundation, and Society for Maternal-Fetal Medicine. Obstet Gynecol 125:653-662

Falik-Zaccai TC, Kfir N, Frenkel P, Cohen C, Tanus M, Mandel H, Shihab S, Morkos S, Aaref S, Summar ML, Khayat M (2008) Population screening in a Druze community: the challenge and the reward. Genet Med 10:903-909

Hendriks YM, Laan LA, Vielvoye GJ, van Haeringen A (1999) Bilateral sensorineural deafness, partial agenesis of the corpus callosum, and arachnoid cysts in two sisters. Am J Med Genet 86:183-186

Henneman L, Borry P, Chokoshvili D, Cornel MC, van El CG, Forzano F, Hall A, Howard HC, Janssens S, Kayserili H, Lakeman P, Lucassen A, Metcalfe SA, Vidmar L, de Wert G, Dondorp WJ, Peterlin B (2016) Responsible implementation of expanded carrier screening. Eur J Hum Genet 24:e1-e12

Holtkamp KC, van Maarle MC, Schouten MJ, Dondorp WJ, Lakeman P, Henneman L (2016) Do people from the Jewish community prefer ancestry-based or pan-ethnic expanded carrier screening? Eur J Hum Genet 24:171-177

Houwen RH, Baharloo S, Blankenship K, Raeymaekers P, Juyn J, Sandkuijl LA, Freimer NB (1994) Genome screening by searching for shared segments: mapping a gene for benign recurrent intrahepatic cholestasis. Nat Genet 8:380-386

Klomp LW, Vargas JC, van Mil SW, Pawlikowska L, Strautnieks SS, van Eijk MJ, Juijn JA, Pabon-Pena C, Smith LB, DeYoung JA, Byrne JA, Gombert J, van der Brugge G, Berger R, Jankowska I, Pawlowska J, Villa E, Knisely AS, Thompson RJ, Freimer NB, Houwen RH, Bull LN (2004) Characterization of mutations in ATP8B1 associated with hereditary cholestasis. Hepatology 40: $27-38$
Lazarin GA, Haque IS, Nazareth S, Iori K, Patterson AS, Jacobson JL, Marshall JR, Seltzer WK, Patrizio P, Evans EA, Srinivasan BS (2013) An empirical estimate of carrier frequencies for 400+ causal Mendelian variants: results from an ethnically diverse clinical sample of 23,453 individuals. Genet Med 15:178-186

Lazarin GA, Hawthorne F, Collins NS, Platt EA, Evans EA, Haque IS (2014) Systematic classification of disease severity for evaluation of expanded carrier screening panels. PLoS One 9:e114391

Littink KW, van Genderen MM, van Schooneveld MJ, Visser L, Riemslag FC, Keunen JE, Bakker B, Zonneveld MN, den Hollander AI, Cremers FP, van den Born LI (2012) A homozygous frameshift mutation in LRAT causes retinitis punctata albescens. Ophthalmology 119:1899-1906

Mathijssen IB, Florijn RJ, van den Born LI, Zekveld-Vroon RC, ten Brink JB, Plomp AS, Baas F, Meijers-Heijboer H, Bergen AA, van Schooneveld MJ (2017) Long-term follow-up of patients with retinitis pigmentosa type 12 caused by CRB1-mutations: a severe phenotype with considerable Interindividual variability. Retina 37: $161-172$

Mathijssen IB, Henneman L, van Eeten-Nijman JM, Lakeman P, Ottenheim CP, Redeker EJ, Ottenhof W, Meijers-Heijboer H, van Maarle MC (2015) Targeted carrier screening for four recessive disorders: high detection rate within a founder population. Eur J Med Genet 58:123-128

Onoufriadis A, Paff T, Antony D, Shoemark A, Micha D, Kuyt B, Schmidts M, Petridi S, Dankert-Roelse JE, Haarman EG, Daniels JM, Emes RD, Wilson R, Hogg C, Scambler PJ, Chung EM, Pals G, Mitchison HM (2013) Splice-site mutations in the axonemal outer dynein arm docking complex gene $\mathrm{CCDC} 114$ cause primary ciliary dyskinesia. Am J Hum Genet 92:88-98

Oorthuys JW, Gons MH, Kwakman JV, Schutgens RB, Tegelaers WH (1985) Screening for raised serum phenylalanine levels in women of reproductive age in Volendam. Ned Tijdschr Geneeskd 129:62-65

Payne M, Rupar CA, Siu GM, Siu VM (2011) Amish, mennonite, and hutterite genetic disorder database. Paediatr Child Health 16:e23e24

Plomp AS, Bergen AA, Florijn RJ, Terry SF, Toonstra J, van Dijk MR, de Jong PT (2009) Pseudoxanthoma elasticum: wide phenotypic variation in homozygotes and no signs in heterozygotes for the c.3775delT mutation in ABCC6. Genet Med 11:852-858

Sallevelt SC, de Koning B, Szklarczyk R, Paulussen AD, de DieSmulders CE, Smeets HJ (2016) A comprehensive strategy for exome-based preconception carrier screening. Genet Med. doi: 10 . 1038/gim.2016.153

Schappert-Kimmijser J, Henkes HE, van den Bosch J (1959) Amaurosis congenita (Leber). AMA Arch Ophthalmol 61:211-218

Tan-Sindhunata MB, Mathijssen IB, Smit M, Baas F, de Vries JI, van der Voorn JP, Kluijt I, Hagen MA, Blom EW, Sistermans E, MeijersHeijboer H, Waisfisz Q, Weiss MM, Groffen AJ (2015) Identification of a Dutch founder mutation in MUSK causing fetal akinesia deformation sequence. Eur J Hum Genet 23:1151-1157

Tardif J, Pratte A, Laberge AM (2017) Experience of carrier couples identified through a population-based carrier screening pilot program for four founder autosomal recessive diseases in SaguenayLac-Saint-Jean. Prenat Diagn. doi: 10.1002/pd.5055

Taschner PE, de Vos N, Post JG, Meijers-Heijboer EJ, Hofman I, Loonen MC, Pinckers AJ, Bleeker-Wagemakers EM, Gardiner RM, Breuning MH (1995) Carrier detection of batten disease (juvenile neuronal ceroid-lipofuscinosis). Am J Med Genet 57:333-337

Teeuw M, Waisfisz Q, Zwijnenburg PJ, Sistermans EA, Weiss MM, Henneman L, Ten Kate LP, Cornel MC, Meijers-Heijboer H (2014) First steps in exploring prospective exome sequencing of consanguineous couples. Eur J Med Genet 57:613-616

Ten Kate LP, Teeuw ME, Henneman L, Cornel MC (2014) Consanguinity and endogamy in the Netherlands: demographic and medical genetic aspects. Hum Hered 77:161-166 
The Genome of the Netherlands Consortium (2014) Whole-genome sequence variation, population structure and demographic history of the Dutch population. Nat Genet 46:818-825

Van Buchem FS, Hadders HN, Ubbens R (1955) An uncommon familial systemic disease of the skeleton: hyperostosis corticalis generalisata familiaris. Acta Radiol 44:109-120

Van Dijk FS, Nesbitt IM, Nikkels PG, Dalton A, Bongers EM, van de Kamp JM, Hilhorst-Hofstee Y, den Hollander NS, Lachmeijer AM, Marcelis CL, Tan-Sindhunata GM, van Rijn RR, Meijers-Heijboer H, Cobben JM, Pals G (2009) CRTAP mutations in lethal and severe osteogenesis imperfecta: the importance of combining biochemical and molecular genetic analysis. Eur J Hum Genet 17:1560-1569
Yzer S, van den Born LI, Schuil J, Kroes HY, van Genderen MM, Boonstra FN, van den Helm B, Brunner HG, Koenekoop RK, Cremers FP (2003) A Tyr368His RPE65 founder mutation is associated with variable expression and progression of early onset retinal dystrophy in 10 families of a genetically isolated population. J Med Genet 40:709-713

Zeegers MP, van Poppel F, Vlietinck R, Spruijt L, Ostrer H (2004) Founder mutations among the Dutch. Eur J Hum Genet 12:591-600

Zlotogora J (2010) The molecular basis of autosomal recessive diseases among the Arabs and Druze in Israel. Hum Genet 128:473-479

Zlotogora J, Carmi R, Lev B, Shalev SA (2009) A targeted population carrier screening program for severe and frequent genetic diseases in Israel. Eur J Hum Genet 17:591-597 